\title{
THE THEORY AND PRACTICE OF UNESCO
}

\author{
ReINHOLD NIEBUHR
}

The United Nations Educational, Scientific and Cultural Organization is in the paradoxical position of performing most useful and necessary functions in the nascent world community but of giving very implausible reasons for the performance of its functions. Assistant Secretary of State George V. Allen, who was until recently responsible for the United States government's UNESCO policy, reported after the Paris UNESCO conference in 1949 that the organization "had a wider public support" and yet was "more widely criticized" than any other international agency. He rightly suggested that the criticisms were prompted by UNESCO enthusiasts who claimed too much for its functions and thus aroused the opposition of realists who did not believe that its contributions to peace were as important as the organization claimed.

It has been my experience that diplomats and foreign office officials of both the United States and other countries are inclined to take a rather cynical attitude toward the whole UNESCO project. If they are challenged they frequently admit the value of what UNESCO does but are critical of the claims it makes for what it does. They resist these claims because their own experience convinces them that the cultural and scientific activities of the organization are not as immediately relevant to the attainment of peace as UNESCO propaganda claims.

The actual functions of UNESCO are impressive. In an inchoate world community, still divided by national barriers of every kind, it works to eliminate barriers and to establish a freer flow of ideas and influences throughout the world. At the recent conference the Director General, Jaime Torres Bodet, refuted the charge that UNESCO is a "merchant of daydreams" by enumerating such programs as the "campaign against the economic obstacles which impede the free circulation of printed materials," the "book coupon scheme designed to enable soft currency countries to obtain books in hard currency countries," the educational missions to the Philippines, Thailand and Afghanistan, the scientific cooperation offices, the fellowships for international exchange of students and teachers, the survey of the technical needs of the mass media in various countries and the efforts to improve the techniques of fundamental education in all countries.

Rernhowd NIeBurm, Professor of Applied Christianity at the Union Theological Seminary, served as a United States representative at the fourth session of the General Conference of UNESCO. 
These items of the program which the Director General briefly enumerated are of course only samples of the total work of the organization. $\mathrm{He}$ could have mentioned the special committee working for a new international copyright convention; projects for the translation of classics in all languages; and seminars designed to establish better understanding across national frontiers in the various disciplines of culture.

Without being too precise the total program might be divided into three categories: a) policies and programs designed to remove national barriers to the free flow of ideas in the world community; b) policies and programs designed to bring the assistance of the more advanced nations to bear upon the educational problems of the less advanced nations; and c) policies and programs intended to overcome misunderstandings between cultures and nations. Such programs include criticism of nationalistic bias in textbooks, seminars and international studies in the various cultural disciplines, exchange of artistic treasures and the encouragement of educational techniques for international amity.

This total program may be criticized for attempting too much. There was in fact a constant demand for "concentration" at the last conference. But it was significant that when actual budget items were considered it proved practically impossible to eliminate any item. The American delegation, for instance, questioned the feasibility of a UNESCO-sponsored "Scientific and Cultural History of Mankind." But the criticism made little impression upon the conference.

The organization may be attempting too much; but no one can deny that the program in general is of tremendous significance in a world community in which the techniques of cultural communication lag far behind the processes of commerce in integrating the world. I would personally be inclined to question the items in the third category most. I am sure that there ought to be as many international conferences as possible in the various sciences and humanistic studies and that UNESCO should facilitate them. But as soon as such conferences seek to become directly relevant to the problem of international peace they are easily betrayed into absurdity. It may be questioned, for instance, whether a conference on "fundamental concepts" designed to clear up semantic difficulties accomplished very much when it came to the conclusion that fortunately all men believe in "democracy" today but that unfortunately they have varying concepts of democracy. Such a study encourages the assumption that nothing but semantic difficulties divide the United States and the Russians. It also tends to obscure the real tragedy of communism which is that it is a system of thought in which a cynical and tyrannical political program is justified by utopian democratic ideals.

This criticism of those activities of UNESCO in which it seeks to make 
its work too directly relevant to the immediate problem of achieving peace brings us to the heart of the organization's problem, namely the fact that it gives wrong reasons for its important functions. In simplest terms the error of UNESCO lies in its claim that its various forms of cultural cooperation are of immediate political significance in resolving overt conflicts in the world community. The UNESCO constitution puts it like this: "Since wars begin in the minds of men it is in the minds of men that the defences of peace must be constructed."

This declaration is not necessarily misleading. Something depends upon the connotation which is given the word "peace." Does the emphasis lie upon the absence of overt conflict? Or does "peace" mean the concord of life and interest which characterizes an integrated community in distinction to social anarchy and chaos? The growing world community requires "peace" in both senses of the term. It is an only partially integrated community, in need of organs of communication and cohesion which will overcome its cultural and ethnic pluralism. But it is also threatened by overt conflict. In the present instance the most serious threat of conflict arises from the tension between two great centers of power, each of which has achieved a political integration of its part of the world, at the expense of dividing the world into two halves. Many of the objections to UNESCO from responsible statesmen arise from the claims, frequently made in behalf of UNESCO, that its functions and services are capable of resolving the conflict between Russia and the west. An important member of the UNESCO secretariat recently protested against the tendency to assign only "long range" functions to the organization. He wanted it understood that it was effective on "short range" problems also. In a similar vein the chairman of the UNESCO executive committee, the Indian Ambassador to Moscow, suggested at the Paris conference that if the east-west conflict were taken out of the hands of politicians and lifted to the UNESCO level it could be solved. He seemed to feel that there was a "spiritual" dimension in the UNESCO program which would resolve overt conflicts which seemed hopeless on the political level. Thus also there are members of the UNESCO secretariat who regard the membership of the satellite nations in the organization as of great significance. Their hope is that UNESCO will in some unexplained way be a "bridge" between Russia and the west.

What can be meant by these hopes? UNESCO undoubtedly facilitates international communication; and communication makes for community. But if one nation or group of nations refuses to participate in the process of communication there is obviously nothing in the process itself which overcomes this recalcitrance. Even if the Russian moral isolation could be overcome and there were a genuine exchange between the two worlds, it does not follow that they would arrive at common conceptions of justice. Nor 
do common conceptions of justice necessarily prevent overt conflict. It is undoubtedly important that the world as a whole achieve some minimal agreements in its conceptions of justice, for diverse conceptions of justice aggravate the danger of conflict. But conflicts of interest and power in any community are possible, even when both parties accept the same principles of justice but are prompted by their interests to give the principles varying interpretations and applications.

The belief that UNESCO programs are directly relevant to the avoidance of overt conflict rests primarily upon the conviction, expressed in the constitution, that "ignorance of each other's ways has been a common cause throughout the history of mankind of that suspicion and mistrust between the peoples of the world through which their differences have all too often broken into war." This proposition is partly true. Ignorance may aggravate fear. But it is not true that knowledge of each other's ways necessarily allays suspicion and mistrust. Some of the most terrible conflicts in history have occurred between neighbors who knew each other quite well, Germany and France for instance. The whole thesis of the direct political relevance of the UNESCO program to the resolution of immediate and overt conflicts in the world community rests to a large degree upon this dubious proposition that conflicts are primarily caused by ignorance of what the parties to a dispute really desire and intend. Actually the most tragic conflicts are between disputants who know very well what the other party intends, but are forced by either principle or interest to oppose it. It is of course possible for a highly integrated community, possessing a rich culture, to establish impartial tribunals with sufficient authority to compose or arbitrate a dispute; and with a sufficiently wise understanding of the points at issue to deflect the disputants from a too direct joining of the issue. But such procedures presuppose something more than an understanding between the disputants. They presuppose a community; and they avail themselves of the community's moral authority as well as of its police force.

It is in short no more possible to make the UNESCO program directly relevant to the resolution of overt conflicts than it is possible to justify the program of a great university by proving that it is directly related to the task of settling a steel strike or a coal strike. The program of a university may greatly contribute to the total moral and intellectual resources of a community and thus be indirectly relevant to the settlement of a given dispute. It may help to perfect the means of arbitration and adjudication and may strengthen the sense of loyalty to a total community in distinction to the party loyalties which are in conflict.

UNESCO must, in short, find its justification in the contributions it makes to the integration of the emergent world community rather than in its supposed but usually illusory contributions to "peace." This fact is for- 
tunately becoming clearer to most of the devotees of the UNESCO program in the various leading nations. Yet the present French Premier, $M$. Bidault, who headed the French delegation at the last UNESCO conference, challenged Secretary Allen's warning against a too uncritical enthusiasm for the UNESCO program, and an unnecessary depreciation of the more purely political instruments of peace. Bidault seemed to suggest that perhaps the United Nations had failed and that UNESCO would succeed in the same realm in which the United Nations had failed.

But even if the emphasis is placed upon the task of integrating the world community, rather than averting or composing overt conflict, the justification of the program in UNESCO circles leaves something to be desired. For the complexities of even this "long range" task are not always fully appreciated. Thus in a public debate on the functions of UNESCO conducted at the Paris conference, eleven out of 27 speakers offered a simple answer to the problem of integrating an ethnically and culturally pluralistic world. They insisted that since the natural sciences were the one truly universal element, it must be the task of UNESCO to strive for the "objectivity" of the natural sciences in the whole world of human affairs. During the directorship of Julian Huxley UNESCO leadership went so far as to suggest that it would be possible to create a culture of "scientific humanism" which would serve as a binding cultural element for the whole world community. Unfortunately there is no possibility of achieving a universally valid culture in these terms. The natural sciences are universal because their methods are more immediately related to the formal principles of reason than the humanities. Yet the universality of mathematics and, to a lesser degree, of logic, have only a slightly binding effect upon a world community. As soon as the principles of reason are used in argument, particularly in arguments about either the meaning of human existence itself, or in arguments about just relations in the community, the premises upon which contrasting arguments rest and the presuppositions of the rational process are more important than the forms of logic. The premises themselves may of course be challenged by rational analysis, but not quite as irrefutably as is usually assumed. Is it possible for instance to prove "scientifically" that a society must not sacrifice too much liberty for the sake of security or too much security for the sake of liberty? We may be able to prove that the essential structure of human nature requires a social system in which due regard is paid both to the unique desires and potentialities of each individual and to the basic securities of all. But there is no logic which will persuade the insecure that they may not be purchasing security at too high a price of liberty; or which will prove to the secure that their estimate of the value of liberty is conditioned by their possession of social security in larger measure than their less privileged fellows. These ideological corruptions 
in all human judgments are not eliminated by scientific objectivity. They are the proof of the existential, rather than purely rational, character of all judgments which men make about each other, about their common life and finally about the meaning of human existence itself.

All historic cultures have a religious pinnacle and a religious foundation which can be neither proved nor disproved by rational analysis. This problem of the religious pluralism of the world community is touched upon in UNESCO circles in only the most oblique fashion, either because of embarrassment in the face of the profundity of the issue or because it is falsely assumed that a rational culture is in the making which will resolve all these religious divergences. But it must be obvious upon even cursory analysis that it is hardly possible to dissolve, let us say, the basic pessimism of Buddhism by proving that life is really worth living; or to refute the limitations of Confucian humanism by proving that it fails to do justice to the heroic elements in human nature; or to challenge Mohammedanism by suggesting that it is based upon a bogus universalism. This does not mean that great historic forces may not destroy one or another of these cultures. Communism may for instance gain tremendous triumphs in China because it satisfies some spiritual, as well as material needs, which Confucian common sense does not satisfy. The adequacy of world cultures and world religions are tested in a crucible of larger proportions than any "objective analysis" by a UNESCO committee.

It is certainly important for a world community to establish a larger degree of tolerance between what seem to be completely incompatible ways of looking at human life and destiny. To this end there must be much more communication between various cultures than in the past. The effort of UNESCO to facilitate communication, whether on the technical level or on the higher level of encouraging exchanges between scholars, is of great importance. But it could be more successful if less ambitious claims were made for the process.

The literacy programs and the support of fundamental educational projects, particularly in backward portions of the world, offer an especially vivid illustration of the "long range" rather than "short range" character of UNESCO activities. Obviously illiteracy is a bar to participation in any but the narrowest and most limited communities. Literacy is therefore a basic pre-condition for participation in a wider world community. The effort to make such literacy programs appear immediately relevant to the cause of "peace" rests upon the dubious assumption that wars spring from ignorance, illiteracy being the most basic and obvious form of such ignorance. Yet modern wars are fought by the most, rather than the least, literate of nations. A very high degree of intelligence is required for the social co- 
operation which modern, or even ancient, wars presuppose. Literacy is therefore no simple guarantor of loyalty to a wider community than the nation. In Russia literacy programs run hand in hand with an increasing subordination of the whole educational process to national interests. But the fact that intelligence may be the servant of particular rather than universal interests does not invalidate literacy programs as a part of a general process of building world community: the ability to read and write is the most fundamental of all the arts of communication by which wider communities are created. The strong nations must come to the assistance of the weaker nations in programs of fundamental education; but they will not be able to sustain these efforts if they labor under illusions about the relation of intelligence to community. For such illusions will give rise to periodic disillusionment. These programs can be justified only in very long range terms.

There are elements in the UNESCO program which have much more immediate significance. It is important, for instance, to pursue an impartial analysis of the text books of all the nations in order that nationalistic prejudices, which color the histories of even the most democratic nations, may be brought under judgment and their elimination be encouraged. Equally important is the UNESCO encouragement of various techniques and programs of education, calculated to encourage international understanding and good will. The new and global community must encourage unifying, and discourage divisive, forces in its world of multifarious cultural forms. But no immediate results can be promised.

The program for the exchange of treasures of arts, for international exhibits and the international visit of orchestras and choruses seeks to cultivate mutual appreciation of the finest elements in the various cultures in addition to mutual helpfulness on the most fundamental levels of culture. Such a program is intrinsically valuable though it would be difficult to prove that it either affected immediate political tensions or made a direct contribution to the world community. In the French Zone of Germany the French have established an extraordinary center of mutual cultural understanding and respect at the University of Tübingen, which excels anything achieved in either the British or American zone. But this does not change the political situation or alter the fact that the French and the Germans live in an atmosphere of political animosity quite different from the political relations between the Germans and the British or the Americans. Recently the Sadler Wells Ballet has made a triumphant tour in America. A high British official humorously inquired of an American friend whether he thought that this triumph would ease the political tensions between the two nations concomitant upon the devaluation of the pound. These intercultural relations 
are not only irrelevant to immediate political tensions; they are not directly, but only indirectly, related to the gradual coalescence of a world community.

"Peace" declares the UNESCO constitution "must be founded, if it is not to fail, upon the intellectual and moral solidarity of mankind." Even if this assertion should be interpreted to mean that world community, rather than peace in the more obvious sense, required the intellectual and moral solidarity of mankind, it is a somewhat questionable proposition. In one sense the intellectual and moral solidarity of mankind is an unattainable goal. The world community will be distinguished from particular national communities for ages to come by the higher degree of heterogeneity in its moral, intellectual, ethnic and linguistic forms of culture. It will be very important to achieve minimal common convictions on standards of justice and to establish degrees of tolerance between disparate cultures which do not now exist. It may perhaps be even more important simply to encourage every possible mode of communication between cultures in order that a common social and cultural tissue may slowly develop. Almost every item in the UNESCO program serves this ultimate end. That end must be its justification. Neither the immediate end of composing overt disputes, nor the slightly more remote end of encouraging obvious understanding between nations is necessarily served by these activities.

If there is a general tendency in UNESCO circles to regard the ultimate end as insufficient and to claim a more immediate and more obvious utility this error may be partly due to a defect in our culture. Our culture has been so accustomed to ask every tomorrow to justify the actions of today, that it does not know how to gain support for responsibilities which are intrinsically right, though they may remain immediately unrewarded. Perhaps we have to learn the meaning of the words: "Seek ye first the Kingdom of God and its righteousness, and all these things shall be added unto you." Sometimes the immediate utility of an action is the more certainly achieved if it is not sought too directly. If for instance we could seek for the economic and moral health of the non-communist world without too much preoccupation with the danger of Russian expansionism, we might well be more successful in averting that expansionism by achieving the health of our own world. In like manner some of "the things to be added" in the realm of world community would be more clearly in our grasp if we did not grasp for them so frantically.

Sometimes UNESCO leaders commit the error of claiming a too immediate and direct relevance for their work because they think that this is the only way of enlisting the enthusiasm of the multitudes. It is indeed a fact that thousands of people are engaged in UNESCO activities in our country alone, who are prompted to their endeavors by illusions. No one can 
deny that some important results have been accomplished in history under the spur of illusion. But illusions are always finally dispelled by the hard facts of history. The work in which UNESCO is engaged requires a "long pull" and not a short one. One could wish therefore that it would be carried on in such a fashion as not to be subject to the enervation of disillusionment. 